\title{
Affinity labeling displays the stepwise activation of ICE-related proteases by Fas, staurosporine, and CrmA-sensitive caspase-8
}

\author{
Atsushi Takahashi ${ }^{1}$, Hirokazu Hirata ${ }^{1}$, Shin Yonehara ${ }^{2}$, Yuzuru Imai ${ }^{2}$, Kyung-Kwon Lee², \\ Richard W Moyer ${ }^{3}$, Peter C Turner ${ }^{3}$, Peter W Mesner ${ }^{4}$, Toshiro Okazaki ${ }^{1}$, Hirofumi Sawai ${ }^{1}$, \\ Shuji Kishi ${ }^{5}$, Kokichi Yamamoto ${ }^{1}$, Minoru Okuma ${ }^{1}$ and Masataka Sasada ${ }^{1,6}$

\begin{abstract}
${ }^{1}$ Department of Hematology and Oncology, Clinical Sciences for Pathological Organs, Graduate School of Medicine, Kyoto University, Kyoto 606; ${ }^{2}$ Department of Viral Oncology, Institute for Virus Research, Kyoto University, Kyoto 606, Japan; ${ }^{3}$ Department of Molecular Genetics and Microbiology, University of Florida College of Medicine, Gainesville, FL 32610-0266; ${ }^{4}$ Division of Oncology Research, Mayo Clinic, Rochester, MN 55905, USA; ${ }^{5}$ Pharmaceutical Basic Research Laboratories, Japan
\end{abstract} \\ Tobacco Inc., Yokohama, Kanagawa 236; ${ }^{6}$ College of Medical Technology, Kyoto University, Kyoto 606, Japan
}

\begin{abstract}
The activation of multiple interleukin-1 $\beta$ converting enzyme-related proteases (caspases) in apoptotic mammalian cells raises questions as to whether the multiple active caspases have distinct roles in apoptotic execution as well as how these proteases are organized in apoptotic signaling pathways. Here we used an affinity-labeling agent, YV(bio)KD-aomk, to investigate the caspases activated during apoptotic cell death. YV(bio)KD-aomk identified six distinct polypeptides corresponding to active caspases in Fas-stimulated Jurkat $T$ cells. On staurosporine treatment, four polypeptides were detected. Competition experiments showed that the labeled caspases have distinct substrate preferences. Stepwise appearance of the labeled caspases in each cell death event was consistent with the view that the activated caspases are organized into protease cascades. Moreover, we found that stepwise activation of caspases similar to that induced by Fas ligation is triggered by exposing non-apoptotic Jurkat cell extracts to caspase-8 (MACH/FLICE/Mch5). Conversely, CrmA protein, a viral suppressor of Fas-induced apoptosis, inhibited the protease activity of caspase-8. Overall, these findings provide evidence that caspase-8, a CrmA-sensitive protease, is responsible for initiating the stepwise activation of multiple caspases in Fas-stimulated cells.
\end{abstract}

Keywords: apoptosis; apoptotic cell death; YV(bio)KDaomk; serpin; Jurkat T cells

\section{Introduction}

Proteases related to interleukin-1 $\beta$-converting enzyme (ICE) play pivotal roles in apoptotic cell death (Takahashi and Earnshaw, 1996). Genetic studies of programmed cell death in Caenorhabditis elegans indicate that a single gene encoding a protease homologous to ICE, ced-3, plays an essential role in all developmental cell death events (Yuan et al., 1993). In mammalian cells, however, multiple genes encoding ICE/CED-3 family proteases have been cloned. A 'caspase' nomenclature (for cysteine protease that

Correspondence: A Takahashi, First Division, Department of Internal Medicine, Faculty of Medicine, Kyoto University, 54 Shogoin Kawara-cho, Sakyo-ku, Kyoto 606-01, Japan

Received 22 January 1997; revised 4 March 1997; accepted 4 March 1997 cleaves after aspartic acid) was recently proposed for human members of this family (Alnemri et al., 1996). The identification of multiple caspases raises several key questions: (i) How many caspases are activated in apoptotic cell death events? (ii) Why are so many proteases activated in the course of apoptosis?

Studies using a cell-free system (Takahashi and Earnshaw, 1997) revealed that multiple caspases are activated in apoptosis (Takahashi et al., 1996a). Those proteases seem to be required for the cleavage of multiple intracellular proteins, which ultimately causes a sudden collapse into apoptotic death (Martin and Green, 1995). The differences in substrate specificities among caspases may allow each caspase to play a distinct role in apoptosis by cleaving its own target(s) (Takahashi et al., 1996a). In support of this notion, while the activity of a lamin-cleaving caspase is required for nuclear fragmentation in the late phase of apoptosis (Lazebnik et al., 1995; Takahashi et al., 1996b), the lamin-cleaving caspase alone cannot initiate chromatin condensation and DNA cleavage (Takahashi et al., 1997b). The coordinated actions of multiple caspases with different roles in the execution of apoptosis seem to be required for its characteristic biochemical and morphological changes.

An attractive hypothesis is that caspases may be organized in enzymatic cascades (Martin and Green, 1995; Chinnaiyan et al., 1996b; Fernandes-Alnemri et al., 1996; Fraser and Evan, 1996). Crystal structures of caspase-1 (ICE) (Walker et al., 1994; Wilson et al., 1994) and caspase-3 (CPP32/Yama/apopain) (Rotonda et al., 1996) suggest that active forms of caspases are tetramers composed of two pairs of large and small subunits, which are derived from two molecules of a precursor by cleavage at multiple Asp-X bonds. This unusual proteolytic processing suggests that caspase activation is driven by autocatalysis, or by cleavage by other caspases (Martin and Green, 1995). It has also been hypothesized that some caspases are responsible for many of the gross biochemical and morphological changes seen in apoptosis, while others are required to activate the former execution caspases (Kumar and Harvey, 1995).

The cascade hypothesis is mainly based on demonstrations that recombinant caspases-1, 3, 4, $6 / \mathrm{a}$, and 10 can process precursor(s) of other caspase(s) (Faucheu et al., 1995; Fernandes-Alnemri et al., 1995b, 1996; Tewari et al., 1995; Liu et al., 1996; Srinivasula et al., 1996). However, most of those data 
were derived from in vitro experiments using recombinant proteins expressed in bacteria, or from analysis of cells in which caspases were overexpressed. The kinetics of the processing of endogenous pro-caspases in Jurkat cells that have internalized granzyme B is different from the results obtained when isolated pro-caspases are incubated with the granzyme in vitro (Froelich et al., 1996). Moreover, even if the pro-caspases are processed to the sizes corresponding to mature forms, it remains to be determined whether the processed procaspases are enzymatically active. For example, the activities of caspases with optimal $\mathrm{pH}$ above 6.5 (Pai et al., 1996) may be suppressed as a result of intracellular acidification, which is a common apoptosis-associated event induced by various stimuli (Gottlieb et al., 1996).

The presence of a protease cascade has also been suggested by the sequential appearances of proteolytic activities cleaving fluorescent YVAD and DEVD substrates (Enari et al., 1996). However, the ability of multiple caspases to cleave YVAD and DEVD tetrapeptide substrates (Fernandes-Alnemri et al., 1996; Henkart, 1996) complicates the interpretation of these results. It remains to be determined if each YVAD- or DEVD-cleaving activity in these experiments is due to the activation of a single caspase, or to the activation of multiple caspases. Moreover, even if multiple DEVD-cleaving caspases are organized in a cascade pathway, the existence of the cascade cannot be revealed by such an approach alone.

Here, we investigated the caspases activated in Fasstimulated and staurosporine-treated Jurkat $\mathrm{T}$ cells using a powerful tool, the affinity-labeling reagent YV(bio)KD-aomk (Thornberry et al., 1994; Takahashi et al., 1996a,b). This reagent covalently binds to the active sites within the large subunits of active caspases (Takahashi et al., 1996a), selectively labeling processed products having proteolytic activities (Yamin et al., 1996). Differences in apparent molecular weight among the labeled proteases enable us to distinguish active caspases from one another (Takahashi et al., 1996a,b). Time-course studies showed that caspases-3, -7/a $(\mathrm{Mch} 3 \alpha / \mathrm{ICE}-\mathrm{LAP} 3 / \mathrm{CMH}-1), \quad-6 / \mathrm{a} \quad(\mathrm{Mch} 2 \alpha)$, and others are activated in a stepwise fashion, suggesting that they are organized into one or multiple protease cascades. In particular, we show that the addition of active caspase-8 (MACH/FLICE/Mch5) to extracts from non-apoptotic Jurkat cells can trigger stepwise activation of caspases that is strikingly similar to that induced by Fas stimulation. Finally, we find that caspase- 8 is sensitive to CrmA, the inhibitor of Fasinduced apoptotic cell death (Enari et al., 1995; Los et al., 1995; Tewari and Dixit, 1995). Taken together, these results support the notion that the activation of multiple caspases is required for the organization of protease cascades as well as for the cleavage of multiple apoptosis-associated substrates.

\section{Results}

Stepwise activation of caspases in apoptotic Jurkat cells revealed by affinity-labeling

In the present study, we employed Fas/APO-1 and staurosporine as inducers of two distinct apoptotic cell death pathways. Fas is the cell-surface receptor for Fas ligand and is implicated in various physiological and pathological processes (Nagata and Goldstein, 1995; Abbas, 1996; Boise and Thompson, 1996; Nagata, 1996). Staurosporine is a broad-spectrum protein kinase inhibitor that is able to induce apoptosis in various types of cells (Bertrand et al., 1994; Jacobson et al., 1996). Jurkat $\mathrm{T}$ cells treated with anti-Fas antibody (Figure 1a) or staurosporine (Figure 1b) underwent apoptotic cell death within a few hours as described previously ( $\mathrm{Na}$ et al., 1996). Cytoplasmic
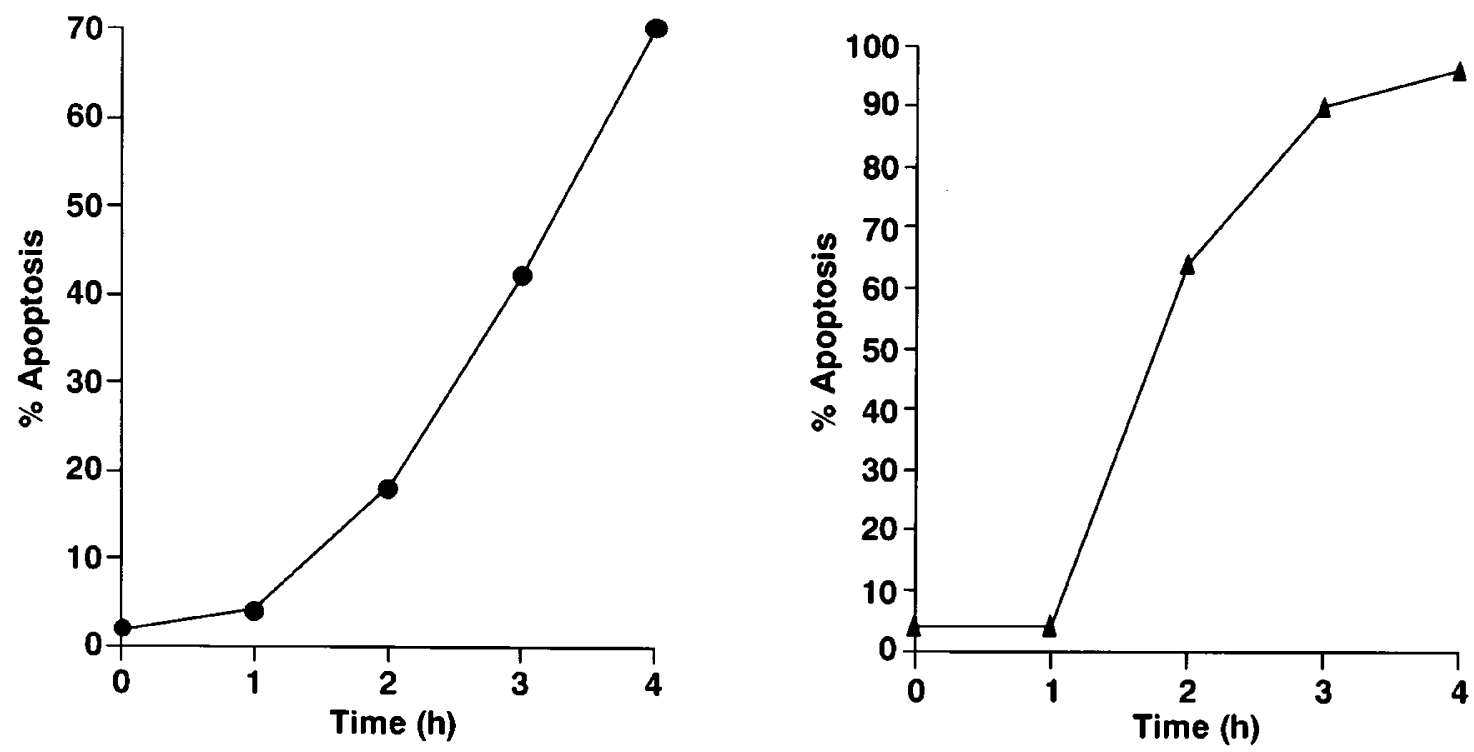

Figure 1 Induction of apoptotic cell death by Fas ligation and by staurosporine. Jurkat T cells were treated with anti-Fas antibody $(\mathrm{CH}-11,100 \mathrm{ng} / \mathrm{ml})$ (a) or with staurosporine $(1 \mu \mathrm{M})(\mathbf{b})$ for the time indicated. The ratio of apoptotic cells were calculated by analysing 100 cells stained with $2 \mu \mathrm{g} / \mathrm{ml}$ DAPI under fluorescent microscope 
extracts from the cells were incubated with the affinitylabeling reagent $\mathrm{YV}(\mathrm{bio}) \mathrm{KD}$-aomk to identify the caspases activated therein (Thornberry et al., 1994; Takahashi et al., 1996a,b).

Lysates from Fas-stimulated cells showed the stepwise appearances of six distinct bands over $3 \mathrm{~h}$. We named the labeled polypeptides F25, F22, F20, F19, F17.5 and F17 on the basis of their migration in $16 \%$ SDS - polyacrylamide gel electrophoresis (SDSPAGE). F17.5 was observed at $30 \mathrm{~min}$ (Figure 2b, upper lane 3) and disappeared after $1 \mathrm{~h}$. F22 and F20 appeared at $1 \mathrm{~h}$ and intensified up to $2 \mathrm{~h}$ (Figure 2a, lanes 2 and 3 ). After $2 \mathrm{~h}$ of exposure to anti-Fas antibody, F25 and F19 became detectable and augmented up to $3 \mathrm{~h}$ (Figure 2a, lanes 3 and 4). F17 first appeared at $2.5 \mathrm{~h}$ (Figure 2b, upper lane 5; Figure 2a, lanes 4 and 5). While F22, F20, F19, and F17 increased in intensity and remained constant after reaching a plateau, F25 peaked at $3 \mathrm{~h}$ and declined in intensity at $4 \mathrm{~h}$ (Figure 2a, lanes 4 and 5). a

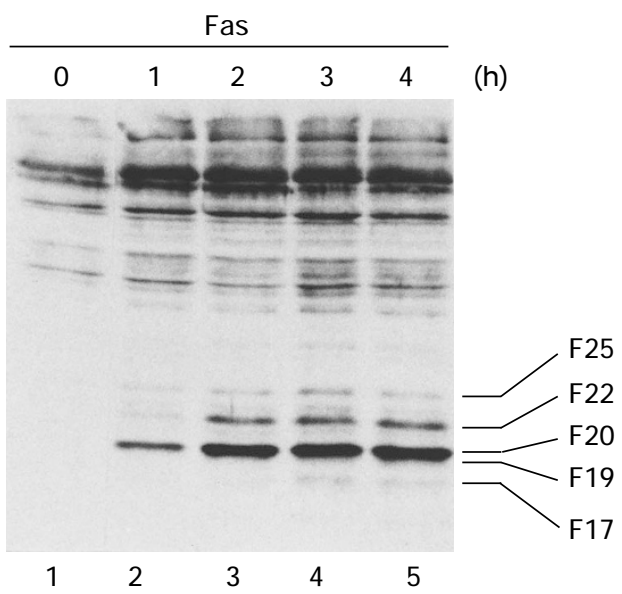

b

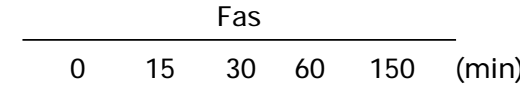

$\mathrm{F} 17.5 \rightarrow$

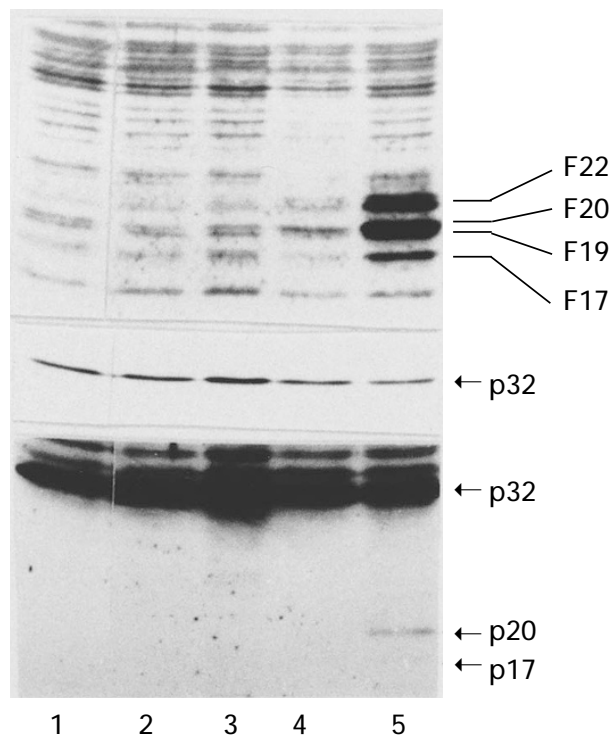

d

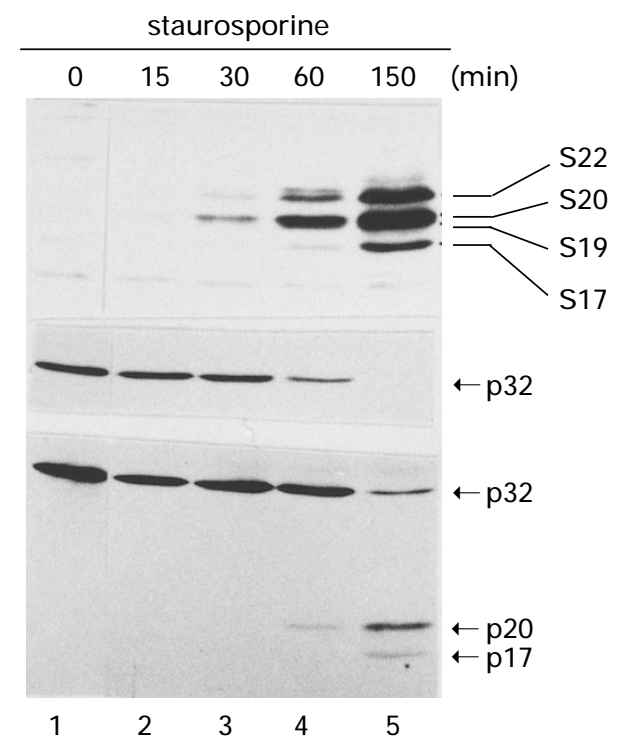

Figure 2 Stepwise activation of caspases in cells undergoing apoptosis. Jurkat cells were treated with anti-Fas antibody (a, b) or with staurosporine $(\mathbf{c}, \mathbf{d})$ for the time indicated. Cytoplasmic extracts $(50 \mu \mathrm{g}$ total protein) obtained from the treated cells were incubated with $100 \mu \mathrm{M} \mathrm{YV(bio)KD-aomk.} \mathrm{The} \mathrm{extracts} \mathrm{were} \mathrm{then} \mathrm{subjected} \mathrm{to} \mathrm{SDS-PAGE} \mathrm{and} \mathrm{blotted} \mathrm{onto} \mathrm{nitrocellulose}$ membranes. (a, c) Labeled proteins were visualized by HRP-conjugated streptavidin and ECL. (b, d) The blots were sequentially probed with HRP-conjugated streptavidin (uppermost lanes), 1:1000 dilution of monoclonal antibody against N-terminal 219 amino acids of caspase-3 (middle lanes), and affinity-purified rabbit antiserum against caspase-3-p17 (lowermost lanes). The positions of pro-caspase-3 (p32), caspase-3-p20 (p20), and caspase-3-p17 (p17) stained with antibodies are indicated by arrows 
Extracts from staurosporine-treated cells showed a similar but not identical pattern. The four major labeled bands were termed S22, S20, S19, and S17. S22 and S20 started to appear at $30 \mathrm{~min}$ (Figure 2d, upper lane 3). S19 and S17 became detectable at $1 \mathrm{~h}$ (Figure 2d, upper lane 4; Figure 2c, lane 2). All of these bands had reached their maximum intensity by $2 \mathrm{~h}$ and remained unchanged up to $4 \mathrm{~h}$ (Figure 2c). Bands corresponding to F25 and F17.5 were not observed. Otherwise, the order of appearances of labeled species was similar, with $30 \mathrm{~min}, 1 \mathrm{~h}$, and $2 \mathrm{~h}$ of staurosporine-treated cells corresponding to $1 \mathrm{~h}, 2 \mathrm{~h}$, and $3 \mathrm{~h}$ of Fas-stimulated cells, respectively. The relative intensities of labeled species varied as F22, F19 and F17 were relatively weaker than S22, S19 and S17, respectively (Figure 2c, lanes 5 and 6).

Labeling required the addition of YV(bio)KD-aomk (Figure 3a, lane 1; Figure 3b, lane 1). The labeled polypeptides of $\mathrm{M}_{\mathrm{r}} 17,20$, and $22 \mathrm{kDa}$ were detected at $1 \mu \mathrm{M}$ of YY(bio)KD-aomk (Figure 3a, lane 2; Figure $3 \mathrm{~b}$, lane 2). Those of $\mathrm{M}_{\mathrm{r}} 19$ and $25 \mathrm{kDa}$ required $10 \mu \mathrm{M}$ for labeling (Figure 3a, lane 3; Figure 3b, lane 3). In all cases, labeling was potently inhibited by $1 \mu \mathrm{M}$ DEVDCHO (Table 1), an aldehyde derivative of a tetrapeptide that binds with high affinity to most caspases (Boldin et al., 1996; Duan et al., 1996b; FernandesAlnemri et al., 1996; Henkart, 1996). These results indicated that the labeled polypeptides represent active caspases. Also, there are significant differences in affinities for YV(bio)KD-aomk among caspases. It remained to be clarified whether caspase(s) exist that have affinities too low to be labeled by YV(bio)KDaomk. The protease activity cleaving DEVD-MCA, a fluorogenic substrate for caspases (Boldin et al., 1996; Duan et al., 1996b; Fernandes-Alnemri et al., 1996; Henkart, 1996), began to rise at $30 \mathrm{~min}$ of Fasstimulation, coincident with the appearance of F17.5, and at 30 min of staurosporine-treatment, synchronous with the appearance of S22 and S20 (Figure 4). Therefore, it was likely that the affinity-labeling method resolved the active caspases responsible for the cleavage of DEVD-MCA.

\section{Differences in substrate recognition properties among activated caspases}

We then pursued the possibility that the multiple caspases activated have different roles in apoptotic execution. To assess whether the active caspases identified by YV(bio)KD-aomk treatment have different substrate preferences reflective of their different roles, we evaluated the effects of inhibitors that mimic substrates (Tables 1 and 2). First, we tested three tetrapeptide aldehyde inhibitors, YVAD-CHO, DEVD$\mathrm{CHO}$, and DMQD-CHO, which have been designed based on the sequence within pro-interleukin-1 $\beta$

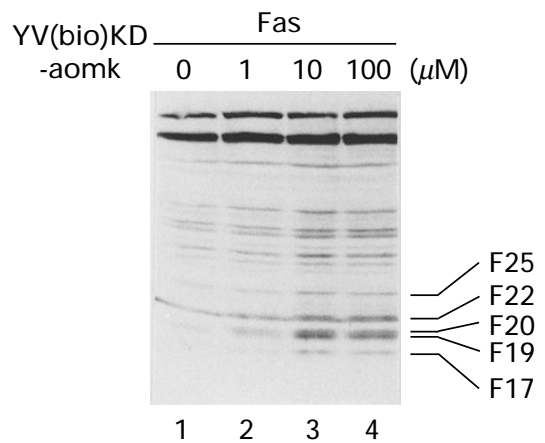

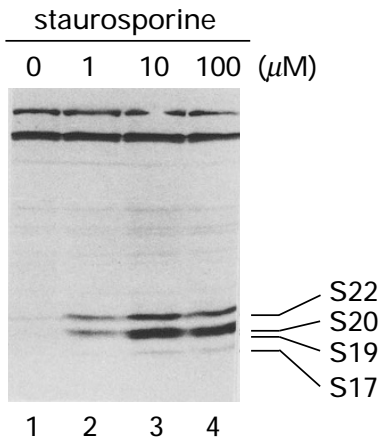

C

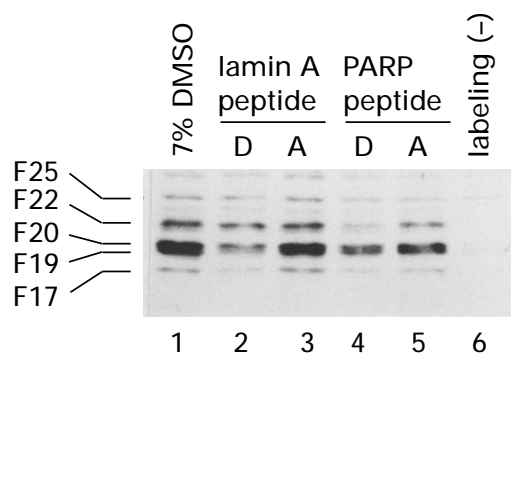

Figure 3 Active caspases have different affinities for YV(bio)KD-aomk, PARP- and lamin A-cleavage site peptides. Cytoplasmic extracts $(20 \mu \mathrm{g}$ total protein) from Jurkat cells treated with anti-Fas antibody for $3 \mathrm{~h}(\mathbf{a})$ or with staurosporine for $2 \mathrm{~h}$ (b) were incubated with 1\% DMSO (lane 1) or with $1 \mu \mathrm{M}$ (lane 2), $10 \mu \mathrm{M}$ (lane 3), and $100 \mu \mathrm{M}$ (lane 4) of YV(bio)KD-aomk. Note that the labeled polypeptides are not detected in the absence of $\mathrm{YV}(\mathrm{bio}) \mathrm{KD}$-aomk (a, lane 1; b, lane 1). (c) Cell lysates (30 $\mu \mathrm{g}$ total protein) from Jurkat cells Fas-stimulated for $3 \mathrm{~h}$ were labeled with $10 \mu \mathrm{M}$ YV(bio)KD-aomk (lanes 1-5) in the presence of $7 \%$ DMSO (lane 1), $7 \mathrm{mg} / \mathrm{ml}$ of lamin A cleavage site peptide (D, RLVEIDNGKQR) (lane 2) and its D to A mutant (A, RLVEIANGKQR) (lane 3), and $2 \mathrm{mg} / \mathrm{ml}$ of PAPR cleavage site peptide (D, GDEVDGIDEV) (lane 4) and its D to A mutant (A, GDEVAGIDEV) (lane 5). Lane 6, no YV(bio)KD-aomk added to the extract. Labeled proteins were visualized with HRP-conjugated streptavidin

Table 1 Effect of DEVD-CHO on YV(bio)KD-aomk binding to caspases

\begin{tabular}{|c|c|c|c|c|c|c|c|c|c|c|c|c|}
\hline & $F 25$ & $F 22$ & $F 20$ & $F 19$ & $F 17$ & $S 22$ & $S 20$ & $S 19$ & S17 & caspase-3 & caspase-4 & caspase-7/a \\
\hline \multicolumn{13}{|c|}{ DEVD-CHO } \\
\hline $1 \mathrm{nM}$ & + & + & + & + & + & + & + & + & + & + & + & + \\
\hline $10 \mathrm{~nm}$ & + & \pm & \pm & + & \pm & \pm & \pm & $+\sim \pm$ & \pm & \pm & + & + \\
\hline $100 \mathrm{nM}$ & - & $\pm \bar{\sim}-$ & $\overline{-}$ & \pm & - & $\pm \bar{\sim}-$ & $\overline{-}$ & \pm & - & - & + & $\pm \sim-$ \\
\hline $1 \mu \mathrm{M}$ & - & - & - & - & - & - & - & $\pm \sim-$ & - & - & + & - \\
\hline $10 \mu \mathrm{M}$ & - & - & - & - & - & - & - & - & - & - & + & - \\
\hline $100 \mu \mathrm{M}$ & - & - & - & - & - & - & - & - & - & - & \pm & - \\
\hline
\end{tabular}

Cytoplasmic extracts $(30 \mu \mathrm{g}$ total protein) from Jurkat cells treated with anti-Fas antibody for $3 \mathrm{~h}$ (F25, F22, F20, F19, F17) or with staurosporine for $2 \mathrm{~h}(\mathrm{~S} 22, \mathrm{~S} 20, \mathrm{~S} 19, \mathrm{~S} 17)$, purified His-tagged caspase-3 (215 pg), and E. coli lysates containing caspase-4 (1.2 $\mu$ g total protein) or caspase-7/a $\left(0.7 \mu \mathrm{g}\right.$ total protein) were pretreated for $15 \mathrm{~min}$ at $37^{\circ} \mathrm{C}$ with DEVD-CHO at concentrations indicated in $10 \mu \mathrm{l}$ mixtures before labeling with $10 \mu \mathrm{M}$ YV(bioKD-aomk. + , no inhibition; $\pm \sim-,<25 \%$ inhibition;, $\pm 25-75 \%$ inhibition; $\pm \sim-, 75-99 \%$ inhibition; - , complete inhibition 


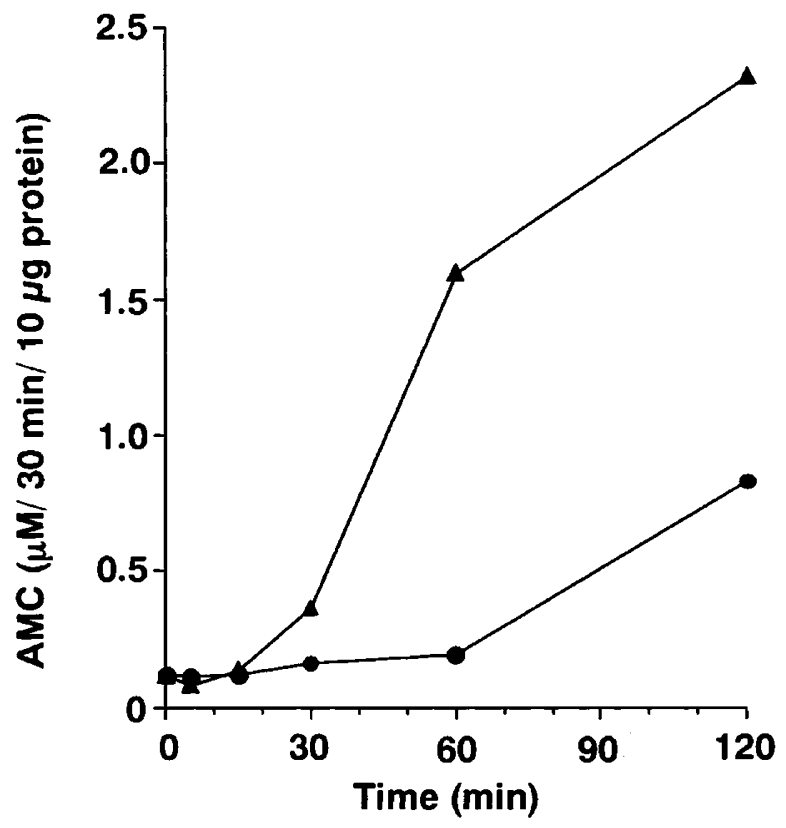

Figure 4 Activation of protease activity that cleaves DEVD MCA by Fas ligation and staurosporine treatment. Cytoplasmic extracts obtained from Jurkat cells $\left(2.5 \times 10^{6}\right)$ treated with antiFas antibody (circles) or with staurosporine (triangles) for the time indicated were incubated with $20 \mu \mathrm{M}$ DEVD-MCA for $30 \mathrm{~min}$ at $37^{\circ} \mathrm{C}$. Concentrations of the released AMC were calculated from the fluorescence measured by a microplate reader and normalized for total protein concentrations of the extracts

recognized by caspase-1 (Thornberry et al., 1992), that within poly(ADP-ribose) polymerase (PARP) recognized by caspase-3 (Nicholson et al., 1995) and caspase-7/a (A Takahashi, unpublished observation), and that within protein kinase $\mathrm{C} \delta$ recognized by caspase-3 (Emoto et al., 1995; Datta et al., 1996).

YVAD-CHO up to $100 \mu \mathrm{M}$ did not affect the labeling of F25, F22, F20, F19, and F17 in cell lysates from Fas-stimulated cells (data not shown). This is consistent with a recent report demonstrating that the protease activity that cleaves YVAD-pNA does not increase after Fas-stimulation of Jurkat cells (Tatsuta et al., 1996). YVAD-CHO up to $100 \mu \mathrm{M}$ similarly failed to affect the labeling of S22, S20, S19, and S17 from staurosporine-treated cells (data not shown).

In contrast, DEVD-CHO caused dose-dependent suppression of the $\mathrm{YV}$ (bio)KD-aomk binding to active caspases (Table 1). Interestingly, the labeled caspases showed different sensitivities to the inhibitor $(\mathrm{F} 20 \approx \mathrm{F} 17>\mathrm{F} 22>\mathrm{F} 25>\mathrm{F} 19 ; \quad \mathrm{S} 20 \approx \mathrm{S} 17>\mathrm{S} 22>\mathrm{S} 19)$. This is consistent with previous studies showing significant differences in $\mathrm{Ki}$ values for DEVD-CHO among caspases (Fernandes-Alnemri et al., 1995b, 1996). Then, the effects of DEVD-CHO on the labeling of recombinant caspases were examined for comparison. Caspases-3, -4, and -7/a showed different sensitivities to DEVD-CHO; that of caspase-3 was identical to F20, F17, S20 and S17, whereas that of the caspase-7/a was similar to F22 and S22. We could not find any labeled caspases in Fas-stimulated or staurosporine-treated cells having the sensitivity to DEVD-CHO similar to that of caspase-4 (TX/ICH-2/ ICErel-II) (Table 1). DMQD-CHO required concentrations at least 100-fold higher than DEVD-CHO to inhibit the caspases activated in Fas- or staurosporinestimulated cells, and showed relative affinities to the activated caspases distinct from DEVD-CHO $(\mathrm{F} 20>\mathrm{F} 22 \approx \mathrm{F} 17>\mathrm{F} 19 ; \quad \mathrm{S} 20>\mathrm{S} 22 \approx \mathrm{S} 17>\mathrm{S} 19) \quad$ (Table 2).

We next analysed the effects of peptides spanning the cleavage site within PARP (Lazebnik et al., 1994) recognized by caspases- 3 and $-7 / \mathrm{a}$ and that within lamin A recognized by caspase-6/a (Takahashi et al., 1996a). These peptides inhibit PARP and lamin A cleavage, respectively, catalyzed either by recombinant caspases or by caspases present in a cell-free system (Lazebnik et al., 1994; Takahashi et al., 1996a). The selective affinities of the cleavage site peptides for PARP- and lamin-cleaving caspases, showing selective inhibition of $\mathrm{YV}(\mathrm{bio}) \mathrm{KD}$-aomk-binding to the proteases, have enabled us to identify these caspases in the cell-free system (Takahashi et al., 1996a,b). PARP peptide had different inhibitory effects on the active caspases in Fas-stimulated $(\mathrm{F} 22>\mathrm{F} 17>\mathrm{F} 20 \approx \mathrm{F} 19$; Figure 3c, lane 4) and staurosporine-treated cells $(\mathrm{S} 22>\mathrm{S} 20 \approx \mathrm{S} 17>\mathrm{S} 19)$ (Table 2). Interestingly, the

Table 2 Inhibitory profiles of YV(bio)KD-aomk-labeled caspases in anti-Fas- and staurosporine-treated cells

\begin{tabular}{|c|c|c|c|c|c|c|c|c|}
\hline & $F 22$ & F20 & $F 19$ & $F 17$ & $S 22$ & $S 20$ & $S 19$ & S17 \\
\hline \multicolumn{9}{|c|}{ DMQD-CHO } \\
\hline $100 \mathrm{nM}$ & + & + & + & + & + & $+\sim \pm$ & + & + \\
\hline $1 \mu \mathrm{M}$ & + & \pm & + & + & + & \pm & + & + \\
\hline $10 \mu \mathrm{M}$ & \pm & - & + & \pm & \pm & - & + & \pm \\
\hline $100 \mu \mathrm{M}$ & - & - & \pm & - & - & - & \pm & - \\
\hline \multicolumn{9}{|c|}{ PARP peptide } \\
\hline $1 \mathrm{mg} / \mathrm{ml}$ & + & + & + & + & + & + & + & + \\
\hline $2 \mathrm{mg} / \mathrm{ml}$ & \pm & + & + & $+\sim \pm$ & \pm & $+\sim \pm$ & $+\sim \pm$ & $+\sim \pm$ \\
\hline $3 \mathrm{mg} / \mathrm{ml}$ & - & - & - & - & - & - & \pm & - \\
\hline \multicolumn{9}{|c|}{ lamin A peptide } \\
\hline $2 \mathrm{mg} / \mathrm{ml}$ & + & + & + & + & + & + & + & + \\
\hline $5 \mathrm{mg} / \mathrm{ml}$ & + & $+\sim \pm$ & \pm & + & + & $+\sim \pm$ & \pm & + \\
\hline $7 \mathrm{mg} / \mathrm{ml}$ & + & \pm & - & \pm & + & \pm & - & \pm \\
\hline \multicolumn{9}{|c|}{ cowpox CrmA } \\
\hline $0.5 \mu \mathrm{M}$ & + & \pm & - & \pm & + & + & \pm & + \\
\hline $1 \mu \mathrm{M}$ & + & \pm & - & \pm & + & \pm & - & \pm \\
\hline $2 \mu \mathrm{M}$ & + & \pm & - & \pm & + & \pm & - & \pm \\
\hline
\end{tabular}

Cytoplasmic extracts $(30 \mu \mathrm{g})$ from Jurkat cells treated with anti-Fas antibody for 3 h (F22, F20, F19, F17) or with staurosporine (S22, S20, S19, $\mathrm{S} 17)$ for $2 \mathrm{~h}$ were pretreated with inhibitors at concentrations indicated in $10 \mu \mathrm{l}$ mixtures before labeling with $10 \mu \mathrm{M} \mathrm{YV}($ bio)KD-aomk. + , no inhibition; $\pm \sim-,<25 \%$ inhibition;, $\pm 25-75 \%$ inhibition; $\pm \sim-, 75-99 \%$ inhibition; - , complete inhibition 
pattern of sensitivity to the PARP peptide (GDEVDGIDEV) was not identical to that to DEVD-CHO. It is likely that the additional amino acid residues endow a higher degree of specificity to the cleavage site peptide. Thus, cleavage site peptides composed of $\sim 10$ amino acids may be useful reagents that cannot be substituted for by tetrapeptide aldehyde inhibitors. At higher concentrations $(3 \mathrm{mg} / \mathrm{ml})$, the PARP cleavage site peptide showed broad spectrum inhibition of all caspases (Table 2). This is reminiscent of the ability of caspases other than caspases-3 and -7/a to cleave PARP, albeit with lower efficiency (Fernandes-Alnemri et al., 1995a; Gu et al., 1995; Duan et al., 1996b; Muzio et al., 1996). The lamin A cleavage site peptide preferentially inhibited F19 and S19, with other caspases showing much lower sensitivities $(\mathrm{F} 19 » \mathrm{~F} 20 \approx \mathrm{F} 17>\mathrm{F} 22 ; \quad \mathrm{S} 19 » \mathrm{~S} 20 \approx \mathrm{S} 17>\mathrm{S} 22 ; \quad$ Figure $3 \mathrm{c}$, lane 2). Changing Asp to Ala within the P1 site markedly reduced the inhibitory effects of both the PARP and the lamin A peptides (Figure 3c, lanes 3 and 5), as previously described (Takahashi et al., 1996a,b). These differences in substrate recognition properties suggested by the inhibitor studies agree with the notion that the activation of multiple caspases in each cell death event reflects the requirement for multiple proteases with distinct functional roles in the execution of apoptosis (Martin and Green, 1995).

We also examined the sensitivity to cowpox virus CrmA, a serpin family protein that is able to inhibit various apoptotic cell death events (Takahashi and Earnshaw, 1996). As shown in Table 2, CrmA protein had distinct inhibitory effects on the labeled caspases $(\mathrm{F} 19 » \mathrm{~F} 20 \approx \mathrm{F} 17>\mathrm{F} 22 ; \quad \mathrm{S} 19 » \mathrm{~S} 20 \approx \mathrm{S} 17>\mathrm{S} 22)$. It has been reported that Fas-induced apoptosis of Jurkat cells is sensitive to $\mathrm{CrmA}$, whereas staurosporine induces $\mathrm{CrmA}$-insensitive apoptotic cell death in the same cells (Chinnaiyan et al., 1996b). However, we could not identify significant differences in CrmA sensitivity between labeled active caspases in Fasstimulated (F22, F20, F19, F17) and staurosporinetreated (S22, S20, S19, S17) cells. We could not assess the ability of CrmA to inhibit F17.5 or F25, because those caspases were only weakly labeled. Also, it could not be excluded that CrmA blocks Fas-induced apoptosis by inhibiting non-caspase protease(s) (Quan et al., 1995).

\section{Identification of YV(bio)KD-aomk-labeled caspases by} inhibitor studies

F19 and S19 were both inhibited by the lamin A cleavage site peptide and were sensitive to cowpox virus CrmA (Table 2). Caspase-6/a, a lamin-cleavage caspase (Takahashi et al., 1996a, 1997a), has been shown to be processed in Fas-stimulated Jurkat cells (Orth et al., 1996). Further, the hamster homologue of caspase-6/a is known to be sensitive to cowpox virus CrmA (Liu et al., 1996). Also, rabbitpox virus CrmA (SPI-2) inhibits the lamin-cleaving caspase in the cytoplasmic extract derived from chicken DU249 cells (Takahashi et al., 1996b). F19 and S19 showed the lowest sensitivity to DEVD-CHO (Table 1) and a previous study indicated that caspase-6/a is not inhibited by DEVD-CHO up to $1 \mu \mathrm{M}$ (Srinivasula et al., 1996). Taken together, these results strongly suggest that F19 and S19 correspond to caspase-6/a.
Immunoblotting using a monoclonal antibody raised against the N-terminal 219 amino acids of caspase-3 revealed an appreciable decrease in pro-caspase- 3 after $1 \mathrm{~h}$ of staurosporine treatment (Figure 2d, middle lane 4 ) and the precursor became almost undetectable at $2 \mathrm{~h}$ (Figure 2d, middle lane 5). Next, we stained the YV(bio)KD-aomk-labeled caspase-3 blotted onto the nitrocellulose membranes with a rabbit antiserum raised against the large subunit of caspase- 3 (caspase3-p17). The antibody revealed two bands at the positions of S20 and S17 (Figure 2d, lower lanes 4 and 5). S20 and S17 showed similar affinities for DEVD-CHO, the PARP and lamin A cleavage site peptides, and CrmA (Tables 1 and 2). Recombinant caspase-3 was as sensitive to DEVD-CHO as S20 and S17 (Table 1). These results strongly suggest that S20 and S17 correspond to the p20 and p17 subunits of caspase-3. The delayed appearance of the p17 subunit is consistent with the slow autocatalytic activity of caspase-3-p20 that cleaves after Asp-29 and yields p17 subunit (Fernandes-Alnemri et al., 1996). Electrophoresis of unlabeled and labeled extracts in the same SDS-PAGE gel, followed by immunoblotting, showed that the migration of caspase-3-p20 and -p17 was retarded as a result of $\mathrm{YV}$ (bio)KD-aomk binding (data not shown). It is of interest that $\mathrm{S} 17$ was less sensitive to DMQD-CHO than S20. Loss of the pro-domain in caspase-3-p17 may affect the substrate recognition property of the enzyme. In contrast, processing of pro-caspase- 3 in Fas-treated cells was minimal up to $4 \mathrm{~h}$ (Figure 2b, middle lanes and data not shown). Staining of YV(bio)KD-aomk-labeled caspase-3 with the rabbit anti-caspase-3-p17 serum detected caspase-3p20 and caspase-3-p17 that comigrated with F20 and F17 after $2.5 \mathrm{~h}$ of Fas-stimulation (Figure 2b, lower lane 5 and data not shown). F20 and F17 had inhibitory profiles almost identical to S20 and S17 (Tables 1 and 2). Thus, F20 and F17 seem to correspond to the minimal amounts of active caspase3 processed in Fas-stimulated cells. However, the possibility remains that $\mathrm{F} 20$ and $\mathrm{F} 17$ also contain other comigrating caspase(s).

Identical mobility in SDS-PAGE gels (Figure 2c, lanes 5 and 6), similar affinity for YV(bio)KD-aomk (Figure $3 \mathrm{a}$ and $\mathrm{b}$ ), and almost identical inhibitory profiles (Tables 1 and 2) implied that F22 is identical to S22. F22/S22 had the highest sensivitiy to the PARP cleavage site peptide (Tables 2 ), raising the possibility that it is a major caspase responsible for the cleavage of PARP in apoptotic Jurkat cells. The highest affinity for PARP may be advantageous in the competition for the same substrate among multiple caspases. Moreover, recombinant caspase-7/a labeled with YV(bio)KDaomk showed the sensitivity to DEVD-CHO almost identical to F22/S22 (Table 1). These results strongly suggest that F22/S22 corresponds to caspase-7/a.

\section{Stepwise activation of caspases induced by caspase- 8}

The stepwise appearances of active caspases with different substrate affinities supported the existence of protease cascades involving multiple distinct caspases. To address this possibility, we examined whether the addition of a purified active caspase can initiate similar activation of multiple caspases in cell-free extracts. The size of F17.5, the active caspase detected earliest in 


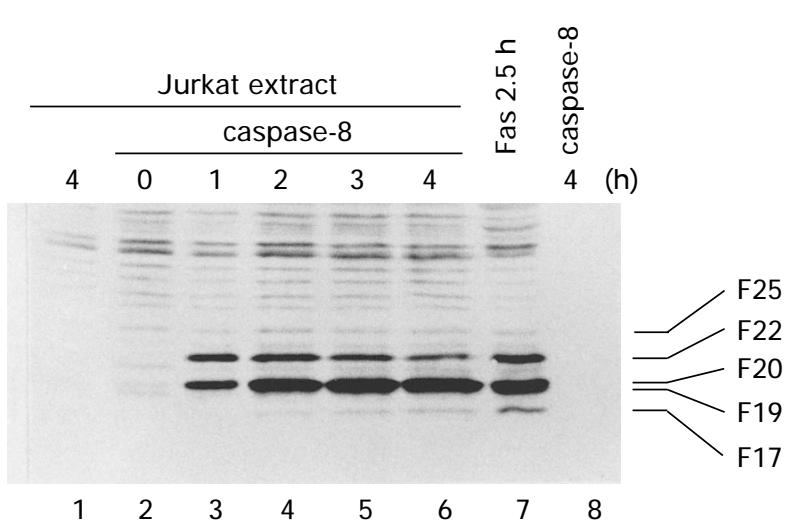

Figure 5 Induction of a putative protease cascade by caspase- 8 . Five $\mu \mathrm{l}$ of purified His-tagged human caspase- 8 dissolved in extract preparation buffer $(136 \mathrm{ng} / \mu \mathrm{l})$ was mixed with $1.5 \mu \mathrm{l}$ of cytoplasmic extracts from normally growing Jurkat cells $(37.5 \mu \mathrm{g} /$ $\mu \mathrm{l})$ and incubated for the times indicated at $37^{\circ} \mathrm{C}$ (lanes $2-6$ ). Jurkat extracts (lane 1) and caspase- 8 (lane 8 ) were mixed with $1.5 \mu \mathrm{l}$ and $5 \mu \mathrm{l}$ of extract preparation buffer, respectively, and incubated for $4 \mathrm{~h}$ at $37^{\circ} \mathrm{C}$. The incubated mixtures were added with $100 \mu \mathrm{M} \mathrm{YV}\left(\right.$ bio)KD-aomk and treated for $5 \mathrm{~min}$ at $37^{\circ} \mathrm{C}$. Lane 7, labeled extracts from Jurkat cells treated with anti-Fas antibody for $2.5 \mathrm{~h}$. The labeled caspases were visualized with HRP-conjugated streptavidin

Fas-stimulated cells, agreed with that of caspase- 8 predicted from cDNA (Thornberry et al., 1997), prompting us to focus on caspase- 8 . Caspase- 8 is implicated in the initiation of a protease cascade in Fas-induced apoptosis (Fraser and Evan, 1996) because Fas ligation recruits pro-caspase- 8 to the plasma membrane via interaction with FADD/MORT1 (Boldin et al., 1996; Muzio et al., 1996). Purified caspase-8 was added to cytoplasmic extracts from normally-growing Jurkat cells and incubated at $37^{\circ} \mathrm{C}$. Within $1 \mathrm{~h}$ of incubation, two bands comigrating with F22 and F20 were observed with YV(bio)KD-aomk labeling (Figure 5, lane 3). At $2 \mathrm{~h}$, a band comigrating with F25 and F19 appeared (Figure 5, lane 4). A band corresponding to F17 was readily discerned at $3 \mathrm{~h}$ after the addition of caspase- 8 (Figure 5, lane 5). No band comigrating with F17.5 was observed. None of those bands appeared in non-apoptotic Jurkat cell extract incubated without caspase- 8 for $4 \mathrm{~h}$ (Figure 5, lane 1). The result indicated that the activation of a single protease, caspase-8, is sufficient to initiate the activation of multiple caspases. Interestingly, the kinetics of caspase activation triggered by caspase- 8 was very similar to that induced in Jurkat cells by Fasstimulation. Purified His-tagged recombinant caspase- 8 showed a faint band that can be detected only on prolonged exposure to the film (Figure 5, lane 8 and data not shown).

\section{CrmA inhibition of caspase-8 activity}

Our results above suggested that caspase- 8 is at the pinnacle of an apoptotic protease cascade induced by Fas ligation. It has been reported that Fas-induced cell death is prevented by CrmA (Enari et al., 1995; Los et al., 1995; Tewari and Dixit, 1995), in contrast to other cell death events such as staurosporine-induced apoptosis (Chinnaiyan et al., 1996b). Interestingly, the protease activity of caspase- 8 as assessed by the cleavage of DEVD-MCA $(\mathrm{Km} \sim 7 \mu \mathrm{M})$ was $\sim 95 \%$ inhibited by preincubation with $100 \mathrm{nM}$ CrmA (Figure 6a). In contrast, the cleavage of VEID-MCA, a tetrapeptide fluorogenic substrate synthesized based on the lamin A cleavage site (Takahashi et al., 1996a), by purified His-tagged caspase-6/a $(\mathrm{Km} \sim 120 \mu \mathrm{M})$ was only $75 \%$ inhibited even with $2 \mu \mathrm{M}$ CrmA (Figure 6a). Real time recordings showed that the addition of $100 \mathrm{nM}$ CrmA to the reaction containing $20 \mu \mathrm{M}$ DEVD-MCA resulted in a time-dependent loss of the protease activity of caspase-8 (Figure 6b). Addition of saturating levels of DEVD-MCA substrate $(200 \mu \mathrm{M}$ $\sim 30 \times \mathrm{Km})$ did not cause the recovery of protease a

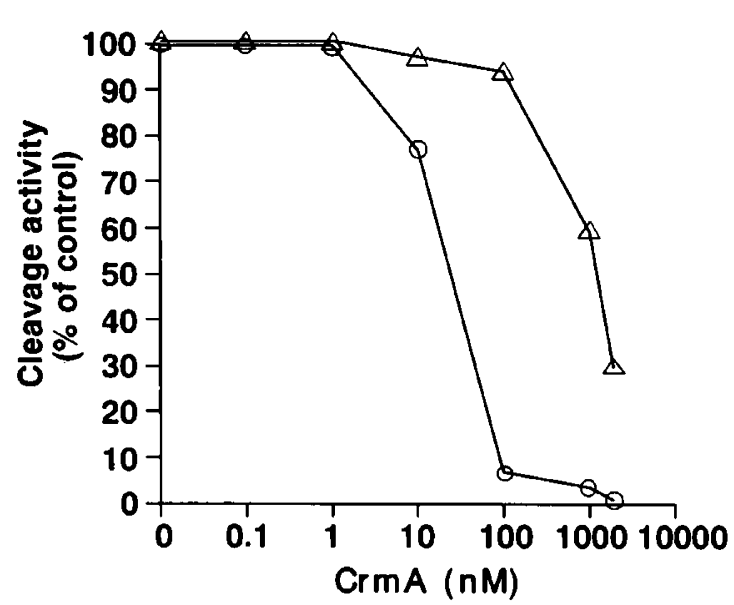

b

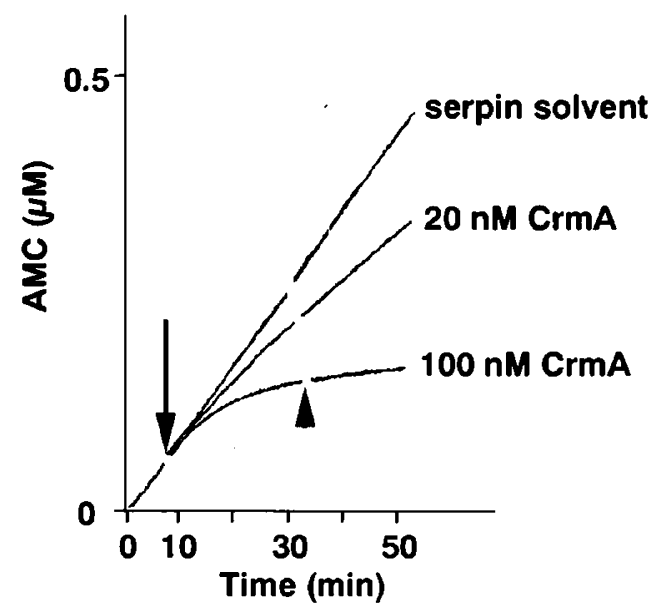

Figure 6 Caspase- 8 is inhibited by cowpox CrmA protein. (a) Dose-dependent inhibition of the protease activities of caspase- 8 (circle) and caspase-6/a (triangle) by CrmA protein. Purified His-tagged caspase-8 (627 ng) or purified His-tagged caspase-6/a $(190 \mathrm{ng})$ were pretreated with $\mathrm{CrmA}$ at concentrations indicated for $20 \mathrm{~min}$ at $37^{\circ} \mathrm{C}$ in $10 \mu \mathrm{l}$ reaction mixtures. The pretreated mixtures were added with $190 \mu \mathrm{l}$ of reaction buffer containing DEVD-MCA (for caspase-8) or VEID-MCA (for caspase-6/a) (final concentrations $20 \mu \mathrm{M}$ ), and incubated for $30 \mathrm{~min}$ at $37^{\circ} \mathrm{C}$. (b) The kinetics of CrmA inhibition of caspase- 8 . Real time recordings were performed at $25^{\circ} \mathrm{C}$ with the excitation wavelength of $380 \mathrm{~nm}$ and the emission wavelength of $460 \mathrm{~nm}$. Caspase- 8 (1.36 $\left.\mu \mathrm{g}\right) \mathrm{was}$ added to $1.5 \mathrm{ml}$ of reaction buffer containing $20 \mu \mathrm{M}$ DEVD-MCA. At the time indicated by an arrow, the reaction mixture was added with $7.5 \mu \mathrm{l}$ of either serpin solvent or CrmA protein at the final concentrations indicated. The arrowhead indicates the addition of DEVD-MCA at the final concentrations of $200 \mu \mathrm{M}$ 
activity (Figure 6b), indicating that suppression of caspase- 8 activity by $\mathrm{CrmA}$ is not through a reversible competitive inhibition. The addition of $\mathrm{CrmA}$ at $100 \mathrm{nM}$ to the continuously-monitored reaction containing $20 \mu \mathrm{M}$ VEID-MCA failed to affect the protease activity of caspase-6/a (data not shown).

\section{Cleavage of CrmA by caspase-8}

A property shared by serpin family proteins is that they often act as both inhibitors of and substrates for their target protease(s) (Gettins et al., 1993). Indeed, CrmA is an inhibitor of and a substrate for human and murine caspase-1 (Komiyama et al., 1994; Xue and Horvitz, 1995). A model has been proposed that the reactive center loop/region of a serpin interacts with the catalytic site of its target protease first, and then the serpin is either cleaved and released from the protease (substrate pathway) or undergoes conformational changes to form a stable inhibitory complex with the protease (inhibitory pathway) (Turner et al., 1995). We examined the possibility that CrmA inhibits caspase- 8 through the same mechanism by checking whether CrmA acts as a substrate for caspase-8. As shown in Figure 7, purified recombinant human caspase- 8 cleaved purified CrmA protein producing a fragment $\sim 5 \mathrm{kDa}$ smaller than the uncleaved protein (lane 3). This cleavage was inhibited by $100 \mu \mathrm{M}$ DEVD-CHO (lane 4), consistent with a proteolytic reaction catalyzed by a caspase. The size of the fragment is compatible with cleavage of $\mathrm{CrmA}$ within its C-terminal reactive center loop/region (Komiyama et al., 1994). Although cleavage of a serpin by a protease does not always signify that the serpin forms a stable complex with the protease (Komiyama et al., 1994), the cleavage of CrmA by caspase- 8 supports a significant interaction between the reactive center region of CrmA and the active site of caspase-8, which can be a basis for transition to the inhibitory pathway (Turner et al., 1995). Given that saturating

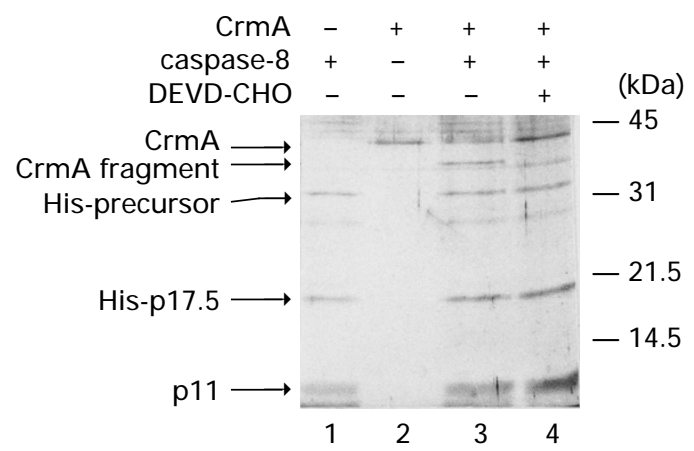

Figure 7 Cleavage of CrmA by caspase-8. Purified caspase- 8 $(2.7 \mu \mathrm{g})$ preincubated in the absence (lanes 1 and 3$)$ or presence of $100 \mu \mathrm{M}$ DEVD-CHO (lane 4) for $15 \mathrm{~min}$ at $37^{\circ} \mathrm{C}$ was mixed with serpin solvent (lane 1) or with 1 pmole of CrmA protein (lanes 3 and 4 ), and incubated for $2 \mathrm{~h}$ at $37^{\circ} \mathrm{C}$. Lane $2, \mathrm{CrmA}$ protein was incubated with extract preparation buffer for $2 \mathrm{~h}$ at $37^{\circ} \mathrm{C}$. The proteins were resolved on a $12.5 \%$ SDS-PAGE gel and visualized by silver staining. Positions of uncleaved CrmA protein $(\mathrm{CrmA}), \mathrm{CrmA}$ cleavage product (CrmA fragment), Histagged pro-caspase-8 (His precursor), His-tagged large subunit of caspase-8 (His-p17.5), and small subunit of caspase-8 (p11) are indicated by arrows. The position of His-tagged caspase-8-p17.5 was compatible with that visualized by labeling with YV(bio)KDaomk (data not shown) levels of DEVD-MCA substrate failed to reverse CrmA inhibition of caspase-8 (Figure 6b), these results suggested that CrmA inhibits caspase- 8 through the mechanism characteristic of serpin family proteins (Gettins et al., 1993).

\section{Discussion}

We used an affinity-labeling method to selectively detect activated caspases in cells undergoing apoptosis. It is formally possible that some of the polypeptides labeled with YV(bio)KD-aomk include non-caspase proteins. However, the YV(bio)KD-aomk-labeling was potently inhibited by nanomolar concentrations of DEVD-CHO, an inhibitor of caspases synthesized based on the cleavage site within a death substrate, PARP. Moreover, inhibition studies showed that the labeled polypeptides detected in Fas-stimulated and staurosporine-treated Jurkat cells have significant affinities for a panel of caspase inhibitors that mimic death substrates. These included DMQD-CHO, the PARP cleavage site peptide, and the lamin A cleavage site peptide. Furthermore, altering D to A within the PARP and lamin A cleavage site peptides markedly decreased their affinities for the YV(bio)KD-aomk-labeled polypeptides. The affinity dependent on the presence of Asp residue at $\mathrm{P} 1$ site of substrates is characteristic of the caspase family proteases. Based on these results, it was concluded that the affinity-labeled proteins detected in the present study represent active caspases.

Since precursors and processing intermediates of caspases may have protease activities (Yamin et al., 1996), the same caspase may generate multiple distinct bands of affinity-labeled polypeptides. Indeed, S20 and S17 correspond to caspase-3-p20 and caspase-3-p17, two large subunits of active caspase- 3 with different degrees of processing. However, no labeled species in the size range expected for pro-caspases were detected in Fas-stimulated or staurosporine-treated Jurkat cells. Further studies are required to delineate whether affinity labeling reagents detect pro-caspases or processing intermediates with protease activities in other cell death events and, if detected, what biological relevance those active precursors have in apoptotic processes.

The methodologies used here proved to be effective tools for identifying the caspases activated during apoptotic cell death. A presumptive identification of labeled species corresponding to caspases-3, -6/a, and $-7 /$ a was made by combining inhibitor studies and immunoblotting with anti-caspase antibody. Although the weak and variable labeling of F17.5 and F25 precluded their identification by inhibitor studies, the size of F17.5 in accord with that of caspase-8 expected from cDNA (Thornberry et al., 1997) and the ability of caspase- 8 to induce active caspases comigrating with those detected subsequent to F17.5 activation (F25, F22, F20, F19, and F17) suggest that F17.5 corresponds to caspase-8. The size of F17.5 is also consistent with that of caspase-10 (Mch4) expected from cDNA (Thornberry et al., 1997). Caspase-10 has a FADD-like domain similar to caspase-8. Its ability to process pro-caspase- 3 and pro-caspase-7/a (FernandesAlnemri et al., 1996) supports the notion that it is one of the apical components of a death cascade composed 
of caspases. However, caspase-10 was not detected in the death-inducing signaling complex associated with activated Fas receptor (Muzio et al., 1996). Although the size of caspase-1 expressed in Sf9 cells and labeled with zEK(bio)D-aomk (Martins et al., 1997) is similar to that of $F 25$, recent studies detected neither the activity to cleave pro-interleukin- $\beta$ nor caspase- 1 protein (Schlegel et al., 1996) in anti-Fas-treated Jurkat cells, despite the detection of caspase-1 mRNA in these cells (Alnemri et al., 1995). The identity of F25 has remained unclear.

Our circumstantial evidence, indicating the activation of caspases-3, -6/a, -7/a, and, very likely, caspase- 8 in Fas-stimulated cells, suggests that only a subset of the pro-caspases expressed in Jurkat cells are activated in apoptotic events, as shown in a previous study (Martins et al., 1997). In the present study, the processing of pro-caspase-3 was minimal in Fasinduced apoptosis in contrast to the complete processing in staurosporine-treated cells. This supports the view that different protease cascades can be activated by different stimuli even in the same cell type (Shi et al., 1996). Schlegel et al. reported that the processing of pro-caspase- 3 begins at $30 \mathrm{~min}$ and is completed by $60 \mathrm{~min}$ in Fas-stimulated Jurkat cells. However, they used a much higher concentration of anti-Fas antibody $(750 \mathrm{ng} / \mathrm{ml})$ (Schlegel et al., 1996), possibly accelerating the kinetics of early steps in the apoptotic process. Gene knockout studies revealed that PARP cleavage and apoptotic cell death in Fasstimulated thymocytes are not affected by loss of caspase-3 (Kuida et al, 1996), indicating that the activation of caspase- 3 is a dispensable process in the Fas-induced cell death pathway. Staurosporine induced a relatively stronger band comigrating with S17 and a relatively weaker band comigrating with S22 in HL-60 myeloid leukemic cells (data not shown), indicating that the content of activated caspases varies depending on cell types even with the same apoptotic stimulus. These suggested that the relative amount of caspases activated in apoptotic cell death events differ with death-inductive stimuli and cell types.

It seems that the power of the affinity-labeling method will yield further insights into the mechanisms of apoptotic cell death by visualizing putative cascade activation of caspases. Here, we demonstrated that the pattern of Fas-induced activation of caspases is recapitulated by exposing extracts from non-apoptotic Jurkat cells to caspase- 8 . This finding seemed more informative than simple demonstrations in vitro that caspase- 8 is able to cleave several recombinant procaspases, because it revealed that caspase- 8 can activate endogenous pro-caspases in non-apoptotic cell extracts and that the kinetics of caspase activation was strikingly similar to that within Fas-stimulated cells. This is compelling evidence that the engagement of Fas receptors can trigger the full activation of caspases simply by the activation of pro-caspase- 8 recruited to the receptors via FADD/MORT1. Furthermore, caspase- 8 was potently inhibited by $\mathrm{CrmA}$, which is inhibitory to Fas-stimulated apoptosis of Jurkat cells though not to that induced by staurosporine (Chinnaiyan et al., 1996b). This finding, in combination with similarities in sensitivity to CrmA of labeled caspases in Fas-stimulated (F22, F20, F19, and F17) and staurosporine-treated (S22, S20, S19, S17) cells, is consistent with the notion that CrmA inhibition of caspase- 8 is responsible for the sensitivity of Fasinduced apoptotic cell death to CrmA (Enari et al., 1995; Los et al., 1995; Tewari and Dixit, 1995). Thus, caspase-8, a CrmA-sensitive protease, appears to be critical for the initiation of the protease cascade in Fasstimulated cells. The action of CrmA on caspase- 8 may also account for CrmA inhibition of apoptosis induced by tumor necrosis factor (TNF) (Enari et al., 1995; Los et al., 1995; Tewari and Dixit, 1995) and by a novel death domain-containing receptor, DR3/WSL-1, related to Fas and TNF receptor 1 (TNFR1) (Chinnaiyan et al., 1996a). TNF binding to TNFR1 and the activation of DR3 can recruit pro-caspase- 8 by forming TNFR1-TRADD-FADD-pro-caspase- 8 and DR3-TRADD-FADD-pro-caspase-8 complexes (Boldin et al., 1996; Chinnaiyan et al., 1996a; Fraser and Evan, 1996; Hsu et al., 1996). Froelich et al. have recently implied that adenovirus-mediated delivery of granzyme B into Jurkat cells induces apoptosis by activating a protease upstream of caspases-3, -6/a, and $-7 /$ a. Since granzyme B can cleave and activate procaspase-8 (Muzio et al., 1996), the authors predict that granzyme B induces apoptosis by activating caspase- 8 (Froelich et al., 1996). Therefore, CrmA may inhibit granzyme B-mediated apoptosis by blocking granzyme B-activated caspase- 8 as well as by suppressing granzyme B directly (Quan et al., 1995).

A potential limitation of the affinity-labeling method is the possible existence of caspases that cannot be labeled by YV(bio)KD-aomk. Indeed, purified active caspase-8 showed only weak labeling with YV(bio)KDaomk, although the presence of mature enzyme was confirmed by the presence of a protease activity cleaving DEVD-MCA, as well as by the detection of processed subunits by silver staining. In Bcl-2inhibitable cell death events, including staurosporineinduced apoptosis of Jurkat cells (Chinnaiyan et al., 1996b), a caspase that does not interact with YVKD or DEVD peptides may act as an initiator of apoptotic pathways (Susin et al., 1996). Development of additional affinity-labeling reagents based on cleavage sites in apoptotic substrates of caspases (Schlegel et al., 1996; Martins et al., 1997) and combinatory use of several labeling reagents will address these problems. A second factor complicating interpretation of the results of these experiments is the inability to exclude that different caspases might migrate indistinguishably close to one another in conventional SDS-PAGE gels. We are addressing this issue by using techniques with much higher resolution, in particular two dimensional gel electrophoresis (Martins et al., 1997).

The strategy described here should be a very effective approach for the study of apoptotic cells from species whose caspases have not been cloned or well characterized. Even for human cells, additional caspase family member(s) may remain to be identified (Susin et al., 1996). The advantage of the affinitylabeling method is that the activation of caspases can be displayed even if specific antisera recognizing caspases are not available (Takahashi et al., 1996a). There may not be close parallels between human caspases and that of the other species. Mouse caspase-1 is only $62 \%$ identical to human caspase- 1 at the amino acid level (Nett et al., 1992; Molineaux et al., 1993). Only one caspase has been cloned from Caenorhabditis 
elegans, while ten caspases have been described in human (Alnemri et al., 1996). Still, however, the competition experiments using cleavage site peptides can demonstrate whether functional homologue(s) of human caspase(s) are activated in the non-human cells by showing substrate specificities of the labeled caspases (Takahashi et al., 1996a,b). As additional apoptosis-associated substrates and their cleavage sites are delineated, peptides spanning these cleavage sites can be used as competitors to identify caspase(s) responsible for their cleavage. The approach may turn out to be more fruitful as additional inhibitors with different affinities for caspases, specific ligands such as specific antibodies which are able to immunodeplete particular caspase(s), and cells from gene-knockout mice deficient in particular caspase(s) become available, enabling us to identify each labeled caspase without complicated procedures such as purification of the labeled caspases and microsequencing. Multiple complementary approaches including cloning, gene targeting, biochemical characterization of each caspase, and the detection of activated caspases within cells using specific antibodies and affinity-labeling reagents, should shed considerable light on the roles of caspases in apoptotic cell death events.

\section{Materials and methods}

\section{Reagents}

DEVD-MCA， VEID-MCA， 7-amino-4-methyl-coumarin (AMC), YVAD-CHO, and DEVD-CHO were purchased from the Peptide Institute (Osaka, Japan), dissolved in dimethyl sulfoxide (DMSO) at $10 \mathrm{~mm}$ and stored at $-80^{\circ} \mathrm{C}$. DMQD-CHO was custom-synthesized at the Peptide Institute. Monoclonal antibody raised against $\mathrm{N}$ terminal 219 amino acids of caspase-3 was obtained from Transduction Laboratories. Polyclonal rabbit antiserum was raised against the large subunit of caspase-3 (caspase3-p17) expressed in E. coli and purified using an affinity column that consists of caspase-3-p17.

Induction of apoptotic cell death and preparation of cytoplasmic extracts

Jurkat T cells $\left(4 \times 10^{6} / \mathrm{ml}\right)$ were treated with $100 \mathrm{ng} / \mathrm{ml}$ antiFas antibody (CH-11) (Yonehara et al., 1989) or $1 \mu \mathrm{M}$ staurosporine (Sigma) for the indicated time periods in serum-free RPMI-1640 (Kikuchi et al., 1995). Harvested cells were washed once with phosphate-buffered saline (PBS), fixed with $1 \%$ glutaraldehyde in PBS, and stained with $2 \mu \mathrm{g} / \mathrm{ml} \mathrm{4}$, 6-diamidino-2-phenylindole (DAPI). Apoptotic cells were counted by analysing the characteristic morphological changes of nuclei by fluorescence microscopy. Cytoplasmic extracts were prepared by five cycles of freezing, thawing, and grinding (microtube homogenizer, ISO, Japan) of cells in extract preparation buffer (Lazebnik et al., 1993) (50 $\mu \mathrm{l} / 10^{7}$ cells), followed by centrifugation for $15 \mathrm{~min}$ at 14000 r.p.m. at $4{ }^{\circ} \mathrm{C}$ to obtain the supernatant.

\section{Affinity labeling of active caspases in cell lysates}

Cell lysates $(20-50 \mu \mathrm{g}$ total protein) were incubated with indicated concentrations of $\mathrm{N}$-(acetyltyrosinylvalinyl- $\mathrm{N}^{\varepsilon}$ biotinyllysyl) aspartic acid [(2,6-dimethylbenzoyl)oxy] methyl ketone (YV(bio)KD-aomk) (Thornberry et al., 1994; Takahashi et al., 1996a) for $5 \mathrm{~min}$ at $37^{\circ} \mathrm{C}$. The samples were then resolved on $16 \%$ SDS-PAGE gels, transferred to nitrocellulose membranes (Hybond ECL, Amersham), and probed with horseradish peroxidase
(HRP)-conjugated streptavidin (Amersham) as described (Takahashi et al., 1996a).

\section{Preparation of recombinant caspases}

cDNAs encoding human caspase-3 (amino acids 29 to 277) (Fernandes-Alnemri et al., 1994) and caspase-6/a (amino acids 24 to 293) (Fernandes-Alnemri et al., 1995a) (kindly provided by Dr Emad S Alnemri) were cloned into the pET-16b vector (Novagen), and the plasmids were transformed into BL21(DE3)pLys (Novagen) E. coli. cDNA encoding Ser-217 through the C-terminus of caspase-8 (MACH $\alpha 1 /$ FLICE protein) (Boldin et al., 1996; Muzio et al., 1996) was PCR-amplified from human HPBALL T cell cDNA library using primers 5'-ACGGGATCCAGTGAATCACAGACTTTGG-3' and 5'-AGCGTCGACTCAATCAGAAGGGAAGACAAG-3', cloned into the pCR-II vector by TA cloning (Invitrogen), and confirmed by sequencing. Caspase- 8 cDNA was then excised from the vector with BamHI and Sal I, inserted into the pQE-30 vector (Qiagen), and transformed into M15[pREP4] E. coli. The N-terminal His-tagged caspases3, -6/a, and -8 were purified from $E$. coli extracts by affinity chromatography with $\mathrm{Ni}^{2+}$-NTA agarose (Qiagen) according to the manufacturer's instructions. Human caspase-4 (Faucheu et al., 1995; Kamens et al., 1995; Munday et al., 1995) and caspase-7/a (Fernandes-Alnemri et al., 1995b; Duan et al., 1996a; Lippke et al., 1996) were expressed in DH $5 \alpha$ E. coli as full-length proteins fused to glutathione-Stransferase at their N-termini. E. coli lysates containing active proteases were prepared as described (FernandesAlnemri et al., 1995a; Takahashi et al., 1996a).

\section{Expression and purification of cowpox virus CrmA protein}

As has been described (Takahashi et al., 1996b), the crmA gene was PCR amplified from genomic DNA of cowpox virus using primers RM233 (5'-GGGCCATGGATATCTTCAGGGAAAT-3') and SM229 (5'-GGACCCGGGTTAACAATTAGTTGTTGGAGAGC-3'), and cloned into pTM1-His vector, which had been constructed by inserting the polyhistidine tract coding region of pET-16b (Novagen) into pTM1 plasmid. The $\mathrm{crm} A$ open reading frame in the resulting plasmid (pTM1-His-crmA) was verified by sequencing. RK-13 cells were infected with recombinant vaccinia virus generated from pTM1-His-crmA. Finally, the $\mathrm{N}$-terminal (His) $)_{10}$-tagged $\mathrm{CrmA}$ protein was purified from the cell lysates with His-Bind resin (Novagen), dissolved in serpin solvent (Takahashi et al., 1996b), and stored at $-80^{\circ} \mathrm{C}$.

\section{Fluorometric assays for caspase activities}

Ten $\mu$ l of cell lysates, purified caspases, or E. coli lysates containing active caspases were added to $190 \mu \mathrm{l}$ of reaction buffer $(100 \mathrm{~mm}$ Pipes, pH 7.4, $10 \%$ sucrose, $5 \mathrm{~mm}$ dithiothreitol, $0.1 \%$ CHAPS, $1 \mathrm{~mm}$ PMSF, $10 \%$ (v/v) aprotinin, $1 \mathrm{mg} / \mathrm{ml}$ each of chymostatin, leupeptin, antipain, pepstatin) containing $20 \mu \mathrm{M}$ of one of two fluorogenic substrates, DEVD-MCA or VEID-MCA. After incubation at $37^{\circ} \mathrm{C}$, reactions were stopped by adding $175 \mu \mathrm{l}$ of $0.2 \mathrm{M}$ glycine- $\mathrm{HCl}, \mathrm{pH} 2.8$. Fluorescence was measured by a microplate reader (MTP-100F, CORONA ELECTRIC, Japan) using $360 \mathrm{~nm}$ excitation and $450 \mathrm{~nm}$ emission filters. Concentrations of AMC liberated as a result of cleavage were calculated using standard AMC solutions. The concentration of proteases and substrates were adjusted so that less than $20 \%$ of the substrates were consumed during the reactions. It had been confirmed that the protease activities were proportional to the amount of enzymes added to the reactions. Real-time recordings of the cleavage of DEVD-MCA or VEID-MCA were 
performed using the reaction buffer containing $20 \mu \mathrm{M}$ substrates as described previously (Takahashi et al., 1997b). For determination of $\mathrm{Km}$ values, the cleavage rate of 1 to $100 \mu \mathrm{M}$ DEVD-MCA by purified recombinant caspase- $8(2.7 \mu \mathrm{g})$ and that of 80 to $300 \mu \mathrm{M}$ VEID-MCA by purified recombinant caspase-6/a $(2.7 \mu \mathrm{g})$ were examined by $5 \mathrm{~min}$ of real-time recordings. $\mathrm{Km}$ values were calculated using the direct linear plot of Cornish-Bowden and Eisenthal (Henderson, 1993).

\section{Inhibitor studies}

Ten $\mu$ of cell lysates or solutions containing active recombinant human caspases were preincubated with YVAD-CHO, DEVD-CHO, or DMQD-CHO for $15 \mathrm{~min}$ at $37^{\circ} \mathrm{C}$, with peptides derived from PARP and lamin A cleavage sites (GDEVDGIDEV and RLVEIDNGKQR) for

\section{References}

Abbas AK. (1996). Cell, 84, 655-657.

Alnemri ES, Fernandes-Alnemri T and Litwack G. (1995). J. Biol. Chem., 270, 4312-4317.

Alnemri ES, Livingston DJ, Nicholson DW, Salvesen G, Thornberry NA, Wong WW and Yuan J. (1996). Cell, 87, 171.

Bertrand R, Solary E, O'Connor P, Kohn KW and Pommier Y. (1994). Exp. Cell Res., 211, 314-321.

Boise LH and Thompson CB. (1996). Science, 274, 67-68.

Boldin MP, Goncharov TM, Goltsev YV and Wallach D. (1996). Cell, 85, 803-815.

Chinnaiyan AM, O'Rourke K, Yu G-L, Lyons RH, Garg M, Duan DR, Xing L, Gentz R, Ni J and Dixit VM. (1996a). Science, 274, 990-992.

Chinnaiyan AM, Orth K, O'Rourke K, Duan H, Poirier GG and Dixit VM. (1996b). J. Biol. Chem., 271, 4573-4576.

Datta R, Banach D, Kojima H, Talanian R, Alnemri ES, Wong WW and Kufe D. (1996). Blood, 88, 1936-1943.

Duan H, Chinnaiyan AM, Hudson PL, Wing JP, He W-W and Dixit VM. (1996a). J. Biol. Chem., 271, 1621-1625.

Duan H, Orth K, Chinnaiyan AM, Poirier GG, Froelich CJ, He W-W and Dixit VM. (1996b). J. Biol. Chem., 271, $16720-16724$

Emoto Y, Manome Y, Meinhardt G, Kisaki HMS, Robertson M, Ghayur T, Wong WW, Kamen R, Weichselbaum $\mathrm{R}$ and Kufe D. (1995). EMBO J., 14, $6148-6156$.

Enari M, Hug H and Nagata S. (1995). Nature, 375, $78-81$.

Enari M, Talanian RV, Wong WW and Nagata S. (1996). Nature, 380, $723-726$.

Faucheu C, Diu A, Chan AWE, Blanchet A-M, Miossec C, Herve F, Collard-Dutilleul V, Gu Y, Aldape RA, Lippke JA, Rocher C, Su MS-S, Livingston DJ, Hercend T and Lalanne J-L. (1995). EMBO J., 14, 1914-1922.

Fernandes-Alnemri T, Litwack G and Alnemri ES. (1994). $J$. Biol. Chem., 269, 30761-30764.

Fernandes-Alnemri T, Litwack G and Alnemri ES. (1995a). Cancer Res., 55, 2737-2742.

Fernandes-Alnemri T, Takahashi A, Armstrong R, Krebs J, Fritz L, Tomaselli KJ, Wang L, Yu Z, Croce CM, Salveson G, Earnshaw WC, Litwack G and Alnemri ES. (1995b). Cancer Res., 55, 6045-6052.

Fernandes-Alnemri T, Armstrong RC, Krebs J, Srinivasula SM, Wang L, Bullrich F, Fritz LC, Trapani JA, Tomasell K, Litwack G and Alnemri ES. (1996). Proc. Natl. Acad. Sci. USA, 93, 7464-7469.

Fraser A and Evan G. (1996). Cell, 85, 781-784.

Froelich CJ, Orth K, Turbov J, Seth P, Gottlieb R, Babior B, Shah GM, Bleackley RC, Dixit VM and Hanna W. (1996). J. Biol. Chem., 271, 29073-29079.
$1 \mathrm{~min}$ on ice, or with $\mathrm{CrmA}$ protein for $20 \mathrm{~min}$ at $37^{\circ} \mathrm{C}$. Caspase activities in the preincubated mixtures were analysed by labeling with YV(bio)KD-aomk or by fluorometric assays.

\section{Acknowledgements}

We are grateful to Dr Emad S Alnemri (Thomas Jefferson University, Philadelphia) for providing cDNAs for caspases-3, -4, -6/a, and -7/a. We thank Dr Alastair M Mackay (Osiris Therapeutics Inc., Baltimore) for critical reading of the manuscript; Drs William $\mathrm{C}$ Earnshaw (University of Edinburgh, Scotland), Katsumi Takada, Kiichiro Nakajima (Peptide Institute, Osaka, Japan), Yota Murakami (Institute for Virus Research, Kyoto University, Japan), and Masanobu Satake (Institute of Development, Aging and Cancer, Tohoku University, Japan) for helpful discussions and suggestions.

Gettins P, Paston PA and Schapira M. (1993). BioEssays, 15 , $461-467$

Gottlieb RA, Nordberg J, Skowronski E and Babior BM (1996). Proc. Natl. Acad. Sci. USA, 93, 654-658.

Gu Y, Sarnecki C, Aldape RA, Livingston DJ and Su M. (1995). J. Biol. Chem., 270, 18715-18718.

Henderson PJF. (1993). Enzyme Assays: A Practical Approach. R Eisenthal and MJ Danson (ed). Oxford University Press: Oxford, pp. $277-316$.

Henkart PA. (1996). Immunity, 4, 195-201.

Hsu H, Shu H-B, Pan M-G and Goeddel DV. (1996). Cell, 84, 299-308

Jacobson MD, Weil M and Raff MC. (1996). J. Cell. Biol., 133, $1041-1051$.

Kamens J, Paskind M, Hugunin M, Talanian RV, Allen H, Banach D, Bump N, Hackett M, Johnston CG, Li P, Mankovich JA, Terranova M and Ghayur T. (1995). J. Biol. Chem., 270, $15250-15256$.

Kikuchi H, Sugiyama S and Imajoh-Ohmi S. (1995). J. Biochem. (Tokyo), 117, 936-939.

Komiyama T, Ray CA, Pickup DJ, Howard AD, Thornberry NA, Peterson EP and Salvesen G. (1994). J. Biol. Chem., 269, 19331 - 19337.

Kuida K, Zheng TS, Na S, Kuan C-Y, Yang D, Karasuyama H, Rakic P and Flavell RA. (1996). Nature, 384, 368-372.

Kumar S and Harvey NL. (1995). FEBS Lett., 375, 169- 173.

Lazebnik YA, Cole S, Cooke CA, Nelson WG and Earnshaw WC. (1993). J. Cell Biol., 123, 7-22.

Lazebnik YA, Kaufmann SH, Desnoyers S, Poirier GG and Earnshaw WC. (1994). Nature, 371, 346-347.

Lazebnik YA, Takahashi A, Moir R, Goldman R, Poirier GG, Kaufmann SH and Earnshaw WC. (1995). Proc. Natl. Acad. Sci. USA, 92, $9042-9046$.

Lippke JA, Gu Y, Sarnecki C, Caron PR and Su MS. (1996). J. Biol. Chem., 271, $1825-1828$.

Liu X, Kim CN, Pohl J and Wang X. (1996). J. Biol. Chem., 271, $13371-13376$.

Los M, Van de Craen M, Penning LC, Schenk H, Westendorp M, Baeuerle PA, Droge W, Krammer PH, Fiers W and Schulze-Osthoff K. (1995). Nature, 375, 81 83

Martin SJ and Green DR. (1995). Cell, 82, 349-352.

Martins LM, Kottke T, Mesner PW, Basi GS, Sinha S, Frigon NJ, Tatar E, Tung JS, Bryant K, Takahashi A, Svingen PA, Madden BJ, McCormick DJ, Earnshaw WC and Kaufmann SH. (1997). J. Biol. Chem., 272, $7421-$ 7430 . 
Molineaux SM, Casano FJ, Rolando AM, Peterson EP, Limjuco G, Chin J, Griffin PR, Calaycay JR, Ding GJ, Yamin TT, Palyha OC, Luell S, Fletcher D, Miller DK, Howard AD, Thornberry NA and Kostura MJ. (1993). Proc. Natl. Acad. Sci. USA, 90, 1809-1813.

Munday NA, Vaillancourt JP, Ali A, Casano FJ, Miller DK, Molineaux SM, Yamin TT, Yu VL and Nicholson DW. (1995). J. Biol. Chem., 270, $15870-15876$.

Muzio M, Chinnaiyan AM, Kishckel FC, O'Rourke K, Shevchenko A, Ni J, Gentz R, Mann M, Krammer PH, Peter ME and Dixit VM. (1996). Cell, 85, 817-827.

$\mathrm{Na}$ S, Chuang TH, Cuningham A, Turi TG, Hanke JH, Bokoch GM and Danley DE. (1996). J. Biol. Chem., 271, $11209-11213$

Nagata S. (1996). Nature Med., 2, 1306-1307.

Nagata S and Goldstein P. (1995). Science, 267, 1449-1456.

Nett MA, Cerretti DP, Berson DR, Seavitt J, Gilbert DJ, Jenkins NA, Copeland NG, Black RA and Chaplin DD. (1992). J. Immunol., 149, 3254-3259.

Nicholson DW, Ali A, Thornberry NA, Vaillancourt JP, Ding CK, Gallant M, Gareau Y, Griffin PR, Labelle M, Lazebnik YA, Munday NA, Raju SM, Smulson ME, Yamin TT, Yu VL and Miller DK. (1995). Nature, 376, $37-43$.

Orth K, Chinnaiyan AM, Garg M, Froelich CJ and Dixit VM. (1996). J. Biol. Chem., 271, $16443-16446$.

Pai J-T, Brown MS and Goldstein JL. (1996). Proc. Natl. Acad. Sci. USA, 93, 5437-5442.

Quan LT, Caputo A, Bleackley RC, Pickup DJ and Salvesen GS. (1995). J. Biol. Chem., 270, 10377-10379.

Rotonda J, Nicholson DW, Fazil KM, Gallant M, Gareau Y, Labelle M, Peterson EP, Rasper DM, Ruel R, Vaillancourt JP, Thornberry NA and Becker JW. (1996). Nat. Struct. Biol., 3, 619-625.

Schlegel J, Peters I, Orrenius S, Miller DK, Thornberry NA, Yamin TT and Nicholson DW. (1996). J. Biol. Chem., 271, $1841-1844$.

Shi L, Chen G, MacDonald G, Bergeron L, Li H, Miura M, Rotello RJ, Miller DK, Li P, Seshadri T, Yuan J and Greenberg AH. (1996). Proc. Natl. Acad. Sci. USA, 93, $11002-11007$.

Srinivasula SM, Fernandes-Alnemri T, Zangrilli J, Robertson N, Armstrong R, Wang L, Trapani JA, Tomaselli KJ, Litwack G and Alnemri ES. (1996). J. Biol. Chem., 271, $27099-27106$

Susin SA, Zamzami N, Castedo M, Hirsch T, Marchetti P, Macho A, Daugas E, Geuskens M and Kroemer G. (1996). J. Exp. Med., 184, 1331-1341.

Takahashi A and Earnshaw WC. (1996). Curr. Opin. Genet. Dev., 6, $50-55$.

Takahashi A, Alnemri ES, Lazebnik YA, FernandesAlnemri T, Litwack G, Moir RD, Goldman RD, Poirier GG, Kaufmann SH and Earnshaw WC. (1996a). Proc. Natl. Acad. Sci. USA, 93, 8395-8400.

Takahashi A, Musy P-Y, Martins LM, Poirier GG, Turner PC, Moyer RW and Earnshaw WC. (1996b). J. Biol. Chem., 271, 32487-32490.
Takahashi A and Earnshaw WC. (1997). Apoptosis: Pharmacology and Therapeutics. SH Kaufmann (ed). Academic Press: San Deigo, CA, in press.

Takahashi A, Alnemri ES, Fernandes-Alnemri T, Lazebnik YA, Moir RD, Goldman RD, Poirier GG, Kaufmann SH and Earnshaw WC. (1997a). Cell Cycle Regulation. B Metcalf, RRJ Ruffolo and G Poste (ed). Harwood Academic Publishers, in press.

Takahashi A, Goldschmidt-Clermont PJ, Alnemri ES, Fernandes-Alnemri T, Yoshizawa-Kumagaya K, Nakajima K, Sasada M, Poirier GG and Earnshaw WC. (1997b). Exp. Cell Res., 231, 123-131.

Tatsuta T, Cheng J and Mountz JD. (1996). J. Immunol., 157, $3949-3957$.

Tewari M and Dixit VM. (1995). J. Biol. Chem., 270, 3255 3260.

Tewari M, Quan LT, O'Rourke K, Desnoyers S, Zeng Z, Beidler DR, Poirier GG, Salvesen GS and Dixit VM. (1995). Cell, 81, 801-809.

Thornberry NA, Bull HG, Calaycay JR, Chapman KT, Howard AD, Kostura MJ, Miller DK, Molineaux SM, Weidner JR, Aunins J, Elliston KO, Ayala JM, Casano FJ, Chin J, Ding GJ-F, Egger LA, Gaffney EP, Limjuco G, Palyha OC, Raju SM, Rolando AM, Salley JP, Yamin TT, Lee TD, Shively JE, MacCross M, Mumford RA, Schmidt JA and Tocci MJ. (1992). Nature, 356, $768-774$.

Thornberry NA, Peterson EP, Zhao JJ, Howard AD, Griffin PR and Chapman KT. (1994). Biochemistry, 33, 39343940.

Thornberry NA, Rosen A and Nicholson DW. (1997). Apoptosis: Pharmacology and Therapeutics. SH Kaufmann (ed). Academic Press: San Diego, CA, in press.

Turner PC, Musy P-Y and Moyer RW. (1995). Viroceptors, virokines and related immune modulators encoded by DNA viruses. G McFadden (ed). RG Landes Company: Austin TX, pp. 67-88.

Walker NP, Talanian RV, Brady KD, Dang LC, Bump NJ, Ferenz CR, Franklin S, Ghayur T, Hackett MC, Hammill LD, Herzog L, Huguin M, Houy W, Mankovich JA, McGuiness L, Orlewicz E, Paskind M, Pratt CA, Reis P, Summani A, Terranova M, Welch JP, Xiong L, Moller A, Tracey DE, Kamen R and Wong WW. (1994). Cell, 78, $343-352$.

Wilson KP, Black JA, Thomson JA, Kim EE, Griffith JP, Navia MA, Murcko MA, Chambers SP, Aldape RA, Raybuck SA and Livingston DJ. (1994). Nature, 370, $270-275$.

Xue D and Horvitz HR. (1995). Nature, 377, 248 - 251.

Yamin T-T, Ayala JM and Miller DK. (1996). J. Biol. Chem., 271, 13273-13282.

Yonehara S, Ishii A and Yonehara M. (1989). J. Exp. Med., 169, $1747-1756$.

Yuan J, Shaham S, Ledoux S, Ellis HM and Horvitz HR. (1993). Cell, 75, 641-652. 